Article

\title{
Generation of Hydrogen, Lignin and Sodium Hydroxide from Pulping Black Liquor by Electrolysis
}

\author{
Guangzai Nong *, Zongwen Zhou and Shuangfei Wang * \\ Received: 26 September 2015; Accepted: 14 December 2015; Published: 25 December 2015 \\ Academic Editor: Animesh Dutta \\ Institute of Light Industry and Food Engineering, Guangxi University, Nanning 530004, China; \\ zongwen_zhou@163.com \\ * Correspondence: gz.nonginguilin@163.com (G.N.); wangsf@gxu.edu.cn (S.W.); \\ Tel.: +86-771-327-2232 (G.N.); Fax: +86-771-323-1590 (G.N.); Tel./Fax: +86-771-323-7097 (S.W.)
}

\begin{abstract}
Black liquor is generated in Kraft pulping of wood or non-wood raw material in pulp mills, and regarded as a renewable resource. The objective of this paper was to develop an effective means to remove the water pollutants by recovery of both lignin and sodium hydroxide from black liquor, based on electrolysis. The treatment of a $1000 \mathrm{~mL}$ of black liquor $(122 \mathrm{~g} / \mathrm{L}$ solid contents) consumed $345.6 \mathrm{~kJ}$ of electric energy, and led to the generation of $30.7 \mathrm{~g}$ of sodium hydroxide, $0.82 \mathrm{~g}$ of hydrogen gas and $52.1 \mathrm{~g}$ of biomass solids. Therefore, the recovery ratios of elemental sodium and biomass solids are $80.4 \%$ and $76 \%$, respectively. Treating black liquor by electrolysis is an environmentally friendly technology that can, in particular, be an alternative process in addressing the environmental issues of pulping waste liquor to the small-scale mills without black liquor recovery.
\end{abstract}

Keywords: black liquor; electrolysis; energy; lignin; hydrogen

\section{Introduction}

Black liquor is a wastewater that is generated in pulp mills during Kraft pulping of wood or non-wood raw materials [1]. Black liquor contains approximately $25 \%-41 \%$ lignin $[2,3]$ and $18 \%-23 \%$ sodium [4] and other dissolved organics (hemicelluloses, cellulose, extractives, etc.), and inorganics. Due to the presence of large amounts of organics, black liquor can be considered as a renewable resource [5]. In a modern pulp mill, black liquor is processed in the so-called black liquor recovery process [6], where the original thin black liquor is concentrated to $65 \%-75 \%$ (wt $\%$ ) and is then combusted in a recovery boiler so that the organics are recovered in the form of steam and electricity while the sodium salts are converted to sodium carbonate and sodium sulfide. For small scale operations, for example, those typically found in Asia, the conventional black liquor recovery process is not economic; instead black liquor is treated following standard industrial waste water treatment technologies, such as aerobic and/or anaerobic systems.

Another process to treat black liquor is the gasification technology so that syngas, and other gases are produced. Such a technology has been under development for the past three decades [7]. The process of black liquor gasification feeds black liquor with a $65 \%-75 \%$ solid content and limited amount of oxygen/air into the gasifier, so that a series of reactions lead to the conversion of the black liquor into $\mathrm{CO}, \mathrm{H}_{2}, \mathrm{CO}_{2}$ and sodium carbonate at high temperatures [8]. Biomass syngas containing $\mathrm{CO}$ and $\mathrm{H}_{2}$ can then be used as the base material to synthesize methanol and dimethyl ether (DME) $[9,10]$ or as a fuel for combustion in a gas turbine to generate power [11]. The generated sodium carbonate is converted into sodium hydroxide via alkalization with slaked lime.

Lignin can be used to generate liquid fuels for internal combustion engines $[12,13]$ and to generate other useful materials $[14,15]$. One way to utilize lignin for the above is to acidify the black 
liquor to $\mathrm{pH}=2-4$ to precipitate the lignin; subsequently, the wet lignin is obtained by filtering the mixture and then further processed [16].

Treating black liquor by combustion and gasification treatments, sodium hydroxide and heat can be recovered; however, lignin is converted into energy and gas pollutants are discharged using these treatments. Treating black liquor by the acidification treatment, recovering the lignin consumes sulfuric acid and loses sodium hydroxide. To date, no method has been found to fully recover both lignin and sodium hydroxide from black liquor. Therefore, we reported herein our results on the generation of hydrogen, lignin and sodium hydroxide from black liquor using the electrolysis concept.

\section{Methods and Materials}

\subsection{Black Liquor}

Black liquor with a concentration of $122 \mathrm{~g} / \mathrm{L}$ of solids and a chemical oxygen demand $\left(\mathrm{COD}_{\mathrm{Cr}}\right)$ of $119,198.4 \mathrm{mg} / \mathrm{L}$ was obtained from the Guangxi Huajing Co., Ltd. (Nanning, China). The black liquor was generated from gumwood/bamboo by sulfite process containing $18 \%$ (wt \%) sodium in the dry black liquor solids. By pyrolysis at $700{ }^{\circ} \mathrm{C}$ for $5 \mathrm{~h}$, the organic compositions were converted completely, remaining mass of residue accounting for $43.8 \%$ of the dry solids. Thereby, the organic components in the dry black liquor are estimated to be $56.2 \%$.

\subsection{Electrolysis of Black Liquor}

The set-up primarily consisted of a cationic electrolytic reactor and a membrane filter, as shown in Figure 1. The cationic electrolytic reactor is the key device in the system [17]; the reactor consisted of a large anode chamber, which is equipped with a cathode plate. A $20 \mathrm{~cm}^{2}$ cationic exchange membrane (CEM) was used as the separation membrane. The working voltage was $4 \mathrm{~V}$, which produced an average $100 \mathrm{~mA}$ of current.

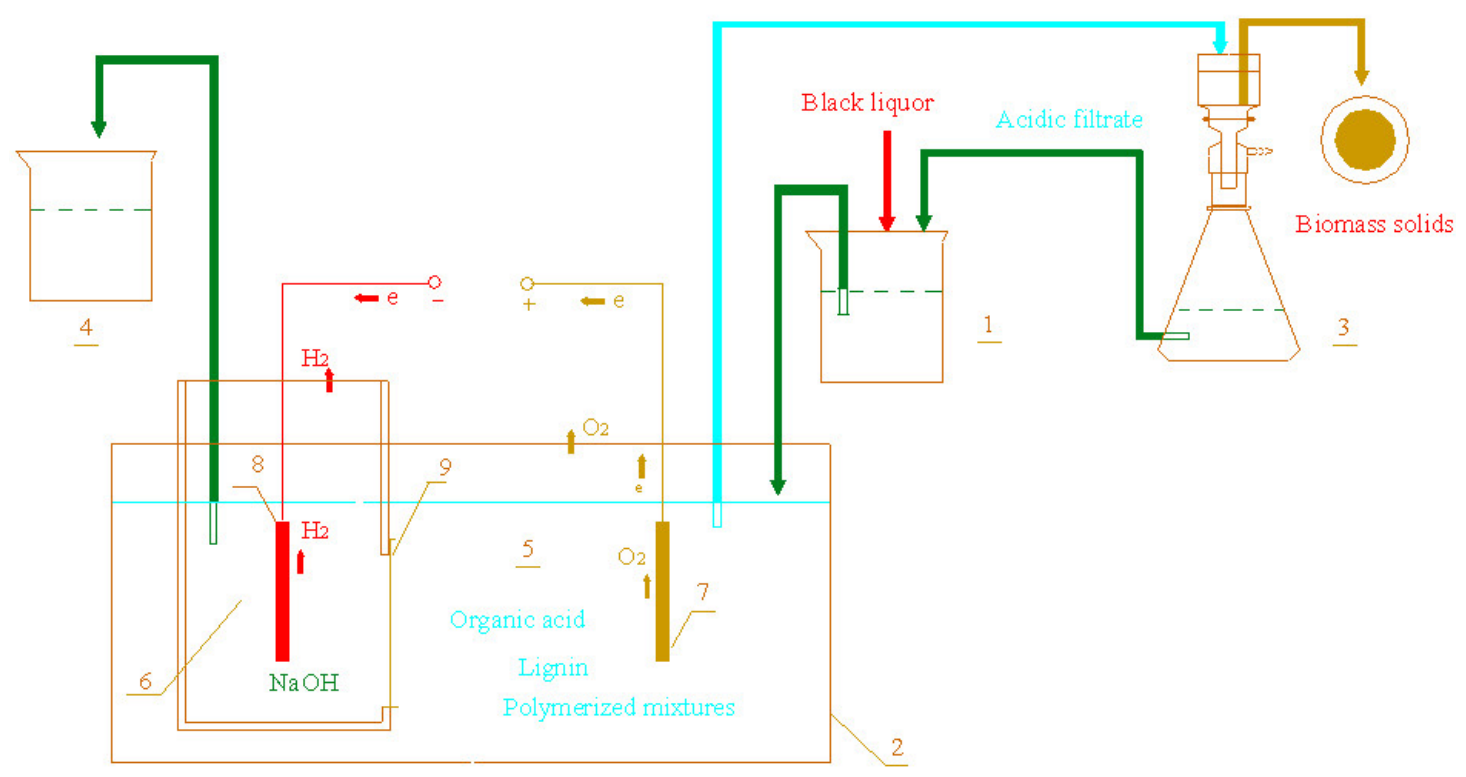

1. Beaker; 2. Electrolytic reactor; 3. filter; 4. NaOH stored; 5. Anode chamber;

6. Cathode chamber; 7. Anode plate; 8. Cathode plate; 9. Cationic membrane.

Figure 1. Experimental set-up of the novel black liquor processing system by electrolysis. 
The electrolysis reactor is utilized in the chlor-alkali and other industries. In the process of water electrolysis, water (with some added electrolyte) is fed into the reactor, producing hydrogen gas and oxygen gas in the cathode and anode chambers, respectively [18]. In the sodium chloride electrolysis process, saturated salt water is fed into the reactor, generating hydrogen gas and sodium hydroxide in the cathode chamber and chlorine gas in the anode chamber. Here, the electrolysis reactor was utilized to treat black liquor, hydrogen gas and sodium hydroxide are generated in the cathode chamber; at the same time, oxygen gas, lignin and other organic precipitates were generated in the anode chamber. A filter was used to remove them from the reactor to maintain the reactor working continually. In addition, the conductivity of diluted black liquor is rather lower; and thereby, it needs greater membrane and plate areas to obtain a suitable production rate.

In comparison with the electrolytic reactor for generating hydrogen fuel from black liquor [19], this black liquor processing system has the following innovations: (1) the space of the electrolytic reactor was separated into a large anode chamber and a cathode plate by a cationic exchange membrane. As a result, besides hydrogen fuel, sodium hydroxide was generated as the main product in the cathode chamber, and the main lignin product was fully precipitated in the anode chamber; (2) the generated hydrogen gas and oxygen gas were generated in the cathode chamber and anode chamber, respectively, and thereby, allowed the generated hydrogen gas be combusted safely; (3) a filter was used to separate the lignin precipitates from the acidified mixture, and thereby, allows the system to work continually.

\subsection{Description of the Treatment Process}

First, $200 \mathrm{~mL}$ of black liquor was diluted to $900 \mathrm{~mL}$ using the recycled acidic filtrate in beaker 1 . Secondly, the diluted solution was fed into the electrolytic reactor 2. In the reactor, $\mathrm{NaOH}$ and $\mathrm{H}_{2}$ were generated in cathode chamber 6; an acidic mixture of different organic acids, lignin and some organic polymers was generated in anode chamber 5 . This acidified mixture was filtered by membrane filter 3 , yielding wet biomass solids (including lignin and other organic precipitates) and an acidic filtrate. Finally, the acidic filtrate was consequently recycled to dilute new $200 \mathrm{~mL}$ black liquor. Operating in $240 \mathrm{~h}, 1000 \mathrm{~mL}$ of black liquor was treated completely, generating as products $\mathrm{NaOH}, \mathrm{H}_{2}$, and biomass solids and consuming electrical energy. The images of biomass precipitating in the diluted solution were shown in Figure S1 (the Section 1 of the supplementary materials).

\subsection{Analytical Methods}

The sodium hydroxide concentrations were determined via titration with a $0.1 \mathrm{M} \mathrm{H}_{2} \mathrm{SO}_{4}$ solution. The low heat value of the organic polymers was determined using a calorimeter. The mass of the residue solids in the acidified filtrate was tried and weighed.

The mass of hydrogen was determined using an infrared analyzer (Gasboard gas analyzer-3100, Sifang Co., Ltd., Wuhan, China) [3]. First, the hydrogen gas generated in the cathode chamber was collected in a tank under water during electrolysis. The collected gas was diluted to $4 \mathrm{~L}$ of total volume with air. Third, the diluted gas was conducted into chamber with dry $\mathrm{CaCl}_{2}$ powder and cotton to absorb the water in the moisture. And the drying gas was consequently conducted into the infrared analyzer to determine the hydrogen concentration. The volume of hydrogen was determined by multiplying the concentration and the diluted volume, and the mass of hydrogen was determined by multiplying the hydrogen gas volume and its density.

The ${ }^{1} \mathrm{H}-\mathrm{Nuclear}$ Magnetic Resonance $\left({ }^{1} \mathrm{H}-\mathrm{NMR}\right)$ analysis were carried out on an AVANCE III HD $600 \mathrm{MHz}$ instrument (Bruke, Karlsruhe, Germany), using DMSO and TMS as solvent and reference, respectively. A Fourier Transform Infrared Spectrometer (FTIR) instrument (Nicolet IS 50, Thermo Fisher Scientific, Waltham, MA, USA), was used for analysis. Each powdered sample was mixed with $\mathrm{KBr}$, and the mixture was pressured in a mould to get a sample plate. Then the sample plates were analyzed in the range of $4000-300 \mathrm{~cm}^{-1}$. 


\section{Results}

\subsection{Identification of Main Products}

As presented in Table 1, treatment of $1000 \mathrm{~mL}$ (122 g/L of solids) black liquor from the process described above, led to the generation of $52.10 \mathrm{~g}$ of dry biomass solids, $30.70 \mathrm{~g}$ of sodium hydroxide and $0.82 \mathrm{~g}$ hydrogen gas. There were still $33.63 \mathrm{~g}$ of residual solids remaining in the acidified filtrate, and there were other amounts of gaseous and volatile compounds released from the system, including $\mathrm{CO}_{2}, \mathrm{O}_{2}$, methanol, ethanol, formic acid, etc. The numbers in Table 1 were obtained by averaging three trials; the recovery ratios of elemental sodium and biomass are $80.4 \%$ and $76 \%$, respectively. The detail calculations were shown in the Section 2 of the supplementary materials, and the reaction of gaseous and volatile compounds generated were shown in Section 3 of the supplementary materials.

Table 1. Masses of products from $1000 \mathrm{~mL}$ black liquor.

\begin{tabular}{cc}
\hline Products & Masses $(\mathbf{g})$ \\
\hline Sodium hydroxide & 30.70 \\
Hydrogen gas & 0.82 \\
Biomass solids & 52.10 \\
Residue solids & 33.63 \\
\hline
\end{tabular}

\subsection{Energy Balance in Treating 1000 mL of Black Liquor}

Figure 2 shows the energy conversions involved in treating $1000 \mathrm{~mL}$ of black liquor. In this process, the energy inputs were: $345.6 \mathrm{~kJ}$ of electrical energy and $1573.8 \mathrm{~kJ}$ of heat of the black liquor; while the outputs were: $1239.49 \mathrm{~kJ}$ and $117.2 \mathrm{~kJ}$ of the heats of biomass solid and hydrogen gas, respectively, and $526.71 \mathrm{~kJ}$ of the residual solids. Determined by a calorimeter, a $23.79 \mathrm{~kJ} / \mathrm{g}$ of the low heat value of biomass solid was obtained and used in the heat calculation. The detail calculations were shown in the Section 4 of the supplementary materials.

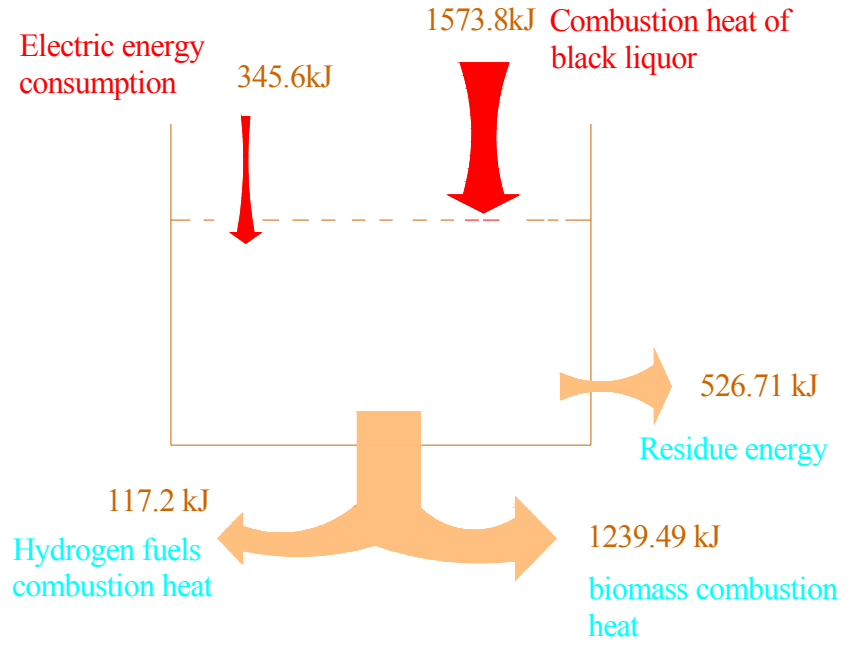

Figure 2. Energy balance involved in treating $1000 \mathrm{~mL}$ of black liquor.

The electric energy consumption for hydrogen generation under the studied conditions was $117.07 \mathrm{kWh} /\left(\mathrm{kg} \mathrm{H}_{2}\right)$, which was significantly higher than $45 \mathrm{kWh} /\left(\mathrm{kg} \mathrm{H}_{2}\right)$ in the water electrolysis for hydrogen [20]. The higher electric energy consumption was due to the higher working voltage used to obtain a high production rate in this study. Additionally, the ratio between the heat of the generated biomass and the heat of black liquor was $78.8 \%$. 


\subsection{Investigation of the Composition of the Biomass Solids}

\subsubsection{Generated Biomass Solids}

Tested by ashing and weight, the generated biomass solids contained $0.32 \%$ of ash. Figure 3 is the FTIR spectrums of biomass solids, lignin and the precipitates from the acidic filtrate. Shown in Figure $3 \mathrm{a}$ is the FTIR spectrums of the generated biomass. Where, the character absorption peaks of lignin at $1512.94 \mathrm{~cm}^{-1}$ and $1603.14 \mathrm{~cm}^{-1}$ were presented. Thereby, the generated biomass solids contain lignin can be identified. Besides the character absorption peaks of lignin, there are character absorption peaks at $3396.45 \mathrm{~cm}^{-1}, 2922.22 \mathrm{~cm}^{-1}$ and $1459.30 \mathrm{~cm}^{-1}$, corresponding to the groups of $-\mathrm{OH},-\mathrm{CH}$ and $-\mathrm{CH}_{2}$, respectively.

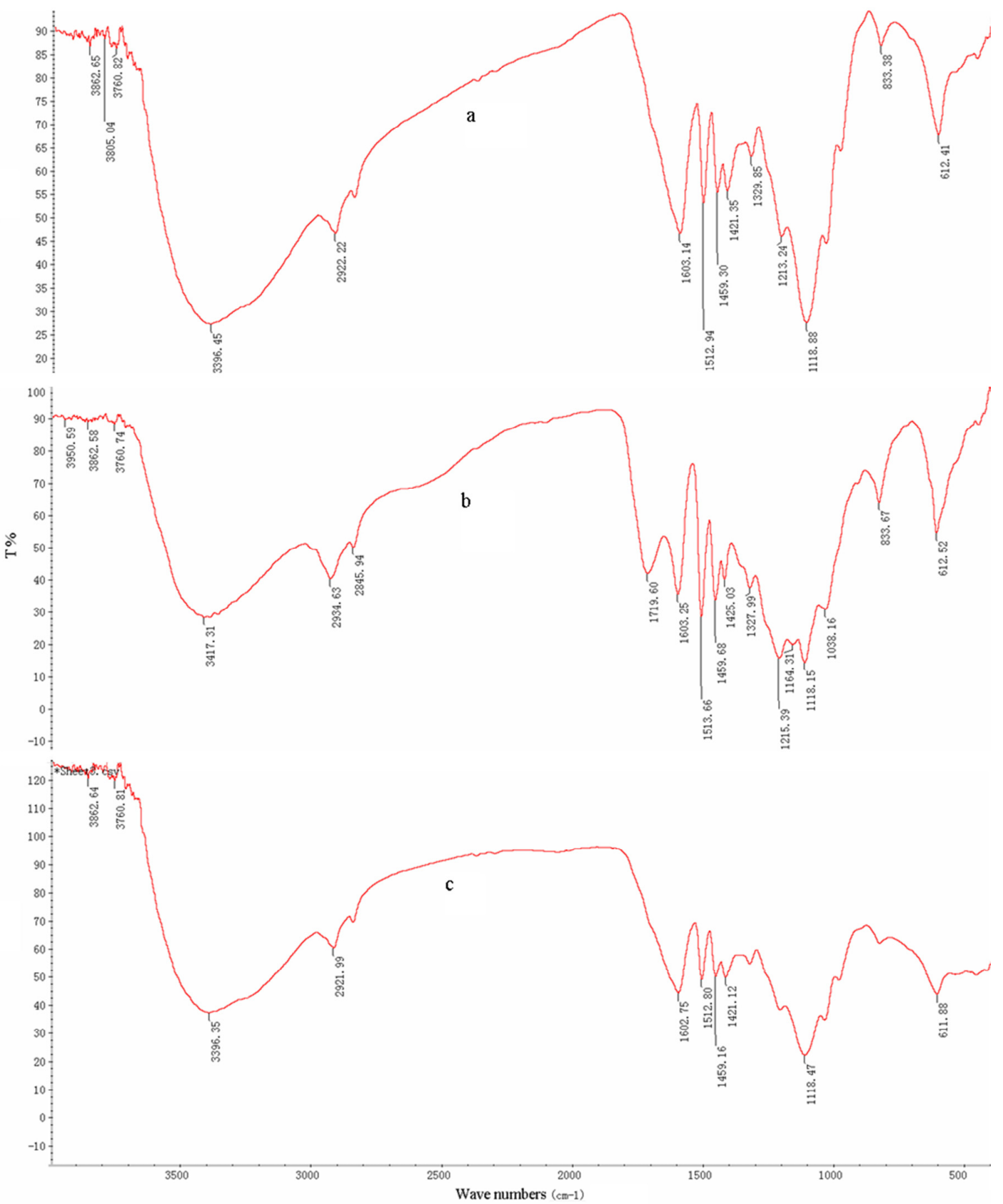

Figure 3. Fourier Transform Infrared Spectrometer (FTIR) spectrums of biomass solids (a); lignin (b) and the precipitates from the acidic filtrate (c). 
Figure 4 shows the ${ }^{1} \mathrm{H}-\mathrm{NMR}$ spectra of biomass solids, lignin and the precipitates from the acidic filtrate. Shown in Figure 4a is the ${ }^{1} \mathrm{H}-\mathrm{NMR}$ spectrum of the generated biomass, where, the characteristic absorption peaks of bamboo lignin at $2.51 \mathrm{ppm}, 3.31 \mathrm{ppm}$ and $3.75 \mathrm{ppm}$ are present. Thereby, the presence of lignin in the generated biomass solids contain was confirmed. The absorption peaks at $1.27 \mathrm{ppm}$ were assigned to $-\mathrm{CH}_{3}$ groups, and the peaks at $2.51 \mathrm{ppm}$ were assigned to $-\mathrm{CH}_{2}$. The absorption peaks at $3.31 \mathrm{ppm}$ and $3.83 \mathrm{ppm}$ were assigned to $-\mathrm{CH}$ groups on the benzene ring. The absorption peaks at 6.4-7.53 ppm, correspond to the $-\mathrm{OH}$ groups.
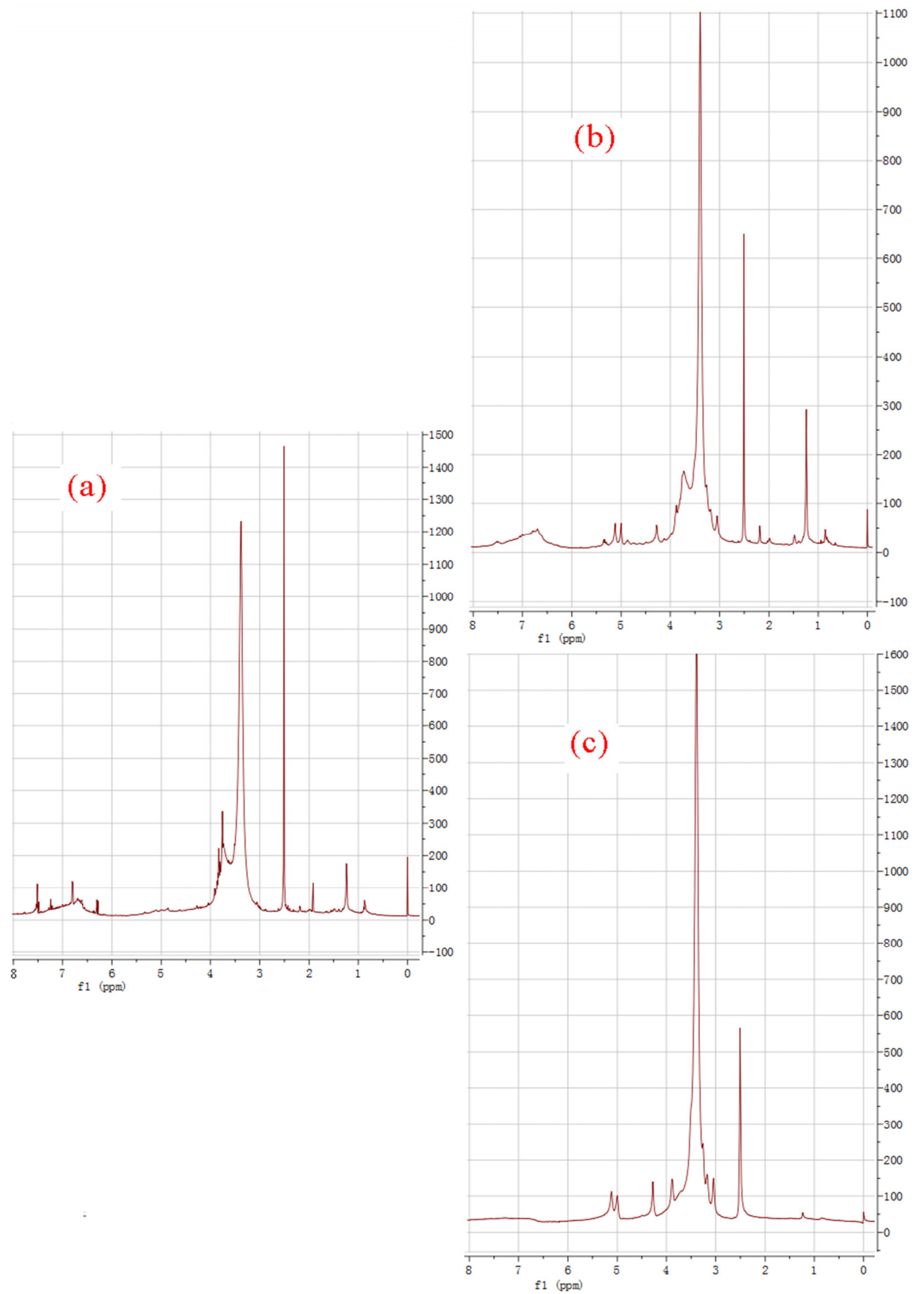

Figure 4. ${ }^{1} \mathrm{H}-\mathrm{Nuclear}$ Magnetic Resonance $\left({ }^{1} \mathrm{H}-\mathrm{NMR}\right)$ spectra of biomass solids (a); lignin (b) and the precipitates from the acidic filtrate $(\mathbf{c})$. 


\subsubsection{Precipitated Lignin}

Additional experiments were performed to further investigate the mass of lignin containing in the generated biomass solids. $1000 \mathrm{~mL}$ of the black liquor was diluted to $2000 \mathrm{~mL}$ of solution, which was consequently acidified with $0.1 \mathrm{M}$ sulfuric acid, yielding $39.8 \mathrm{~g}$ of lignin and $2000 \mathrm{~mL}$ of acidic filtrate. Thereby, the biomass solids generated by electrolysis was regarded as containing $39.8 \mathrm{~g}$ of lignin. Besides lignin, there was $12.3 \mathrm{~g}$ of other organic precipitates contained in the biomass solids. Shown in Figure $3 b$ is the FTIR spectrum of the lignin precipitated by sulfuric acid. Besides the characteristic absorption peaks of lignin at $1513.66 \mathrm{~cm}^{-1}$ and $1603.25 \mathrm{~cm}^{-1}$, there are characteristic absorption peaks at $3396.35 \mathrm{~cm}^{-1}, 2921.99 \mathrm{~cm}^{-1}$ and $1459.16 \mathrm{~cm}^{-1}$, corresponding to the $-\mathrm{OH},-\mathrm{CH}$ and $-\mathrm{CH}_{2}$ groups, respectively. Shown in Figure $4 \mathrm{~b}$ is the ${ }^{1} \mathrm{H}-\mathrm{NMR}$ spectrum of the lignin precipitated by sulfuric acid, presenting the absorption peaks of bamboo lignin at $1.25 \mathrm{ppm}, 2.51 \mathrm{ppm}$, and 3.31 and $3.75 \mathrm{ppm}$. As mentioned ahead, those peaks were assigned to the $-\mathrm{CH}_{3},-\mathrm{CH}_{2}$, and $-\mathrm{CH}$ groups, respectively.

\subsubsection{Other Organic Precipitates}

Additional experiments were performed to further investigate the generation of the other organic precipitates. After removed lignin by filtration, the remaining $2000 \mathrm{~mL}$ of acidic filtrate was fed into the electrolytic reactor and electrolyzed for $96 \mathrm{~h}$. As a result, precipitates were formed, yielding $12.3 \mathrm{~g}$ of dry residue solids. Thereby, the generated biomass solids contained $12.3 \mathrm{~g}$ of other organic precipitates that can be identified. Shown in Figure $3 \mathrm{c}$ is the FTIR spectrum of the organic precipitates generated from the acidic filtrate. There are mainly characteristic peaks at $1512.80 \mathrm{~cm}^{-1}$ and $1602.75 \mathrm{~cm}^{-1}$, corresponding to the small units of lignin, thereby, we conclude that the precipitates generated from the acidic filtrate contain small lignin units. Shown in Figure $4 \mathrm{c}$ is the ${ }^{1} \mathrm{H}-\mathrm{NMR}$ spectrum of the organic precipitates generated from the acidic filtrate. They contained small lignin units, and thereby, its ${ }^{1} \mathrm{H}-\mathrm{NMR}$ contained the characteristic absorption peaks of bamboo lignin at $2.50 \mathrm{ppm}, 3.34 \mathrm{ppm}$. However, the peak at $1.25 \mathrm{ppm}$ assigned to $-\mathrm{CH}_{3}$ groups was much smaller and the peak at 3.75 was absent, indicating that the structure of the organic precipitates from the acidic filtrate was somewhat different from that of the lignin precipitated by sulfuric acid and the precipitates obtained by electrolysis. The organic polymerized and precipitated from the acidified filtrate were shown in the Section 5 of the supplementary materials.

\subsection{Investigation of the Working Mechanisms of Black Liquor Electrolysis}

As shown in Figure 5, the working mechanisms of black liquor electrolysis are described as follows.

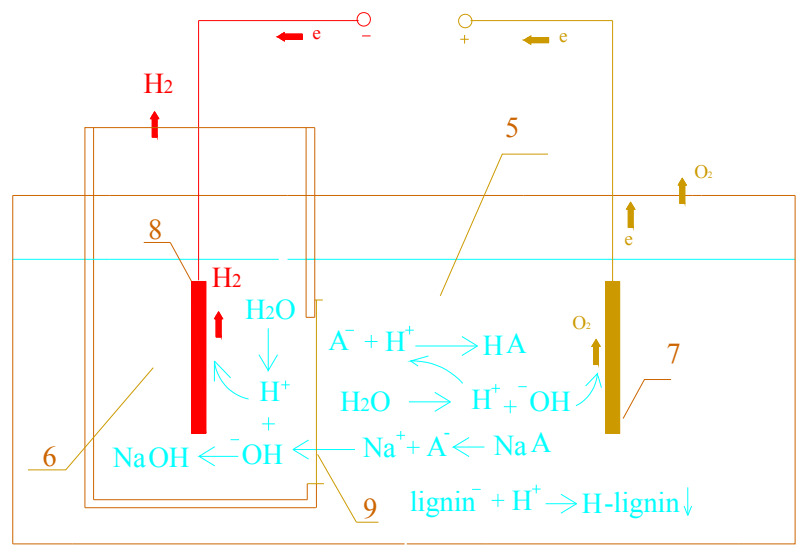

5. Anode chamber; 6. Cathode chamber; 7. Anode plate;

8. Cathode plate; 9. Cationic exchange membrane.

Figure 5. Working mechanisms of black liquor electrolysis. 
Black liquor contains sodium lignin and sodium salts of organic acids (NaA), such as sodium form acid and acetate. The sodium lignin dissociates to $\mathrm{Na}^{+}$and lignin anion (lignin ${ }^{-}$), and the sodium salts of organic acids dissociate to $\mathrm{Na}^{+}$and organic acidic anions $\left(\mathrm{A}^{-}\right)$in solution. Selective blocking by the cationic exchange membrane prevented the organic acidic ions from penetrating the membrane, while the $\mathrm{Na}^{+}$can penetrate the membrane and transfer into the cathode chamber [21]. In the cathode chamber, the dissociated $\mathrm{H}^{+}$ions accept electrons and become hydrogen gas when they touched the cathode [22]; and the remaining -OH combines with the incoming $\mathrm{Na}^{+}$to form sodium hydroxide. In the anode chamber, the dissociated $-\mathrm{OH}$ ions lose electrons and become oxygen gas and water upon contacting with the anode [23]; and the remaining $\mathrm{H}^{+}$ions combine with the remain inorganic acidic ions $\left(\mathrm{A}^{-}\right)$to generate organic acids (HA) [22]. The reactions of sodium hydroxide and lignin generation are expressed as Equations (1)-(8). The generation of organic acid led to the lignin precipitation, which mechanisms are shown as Figure 6.

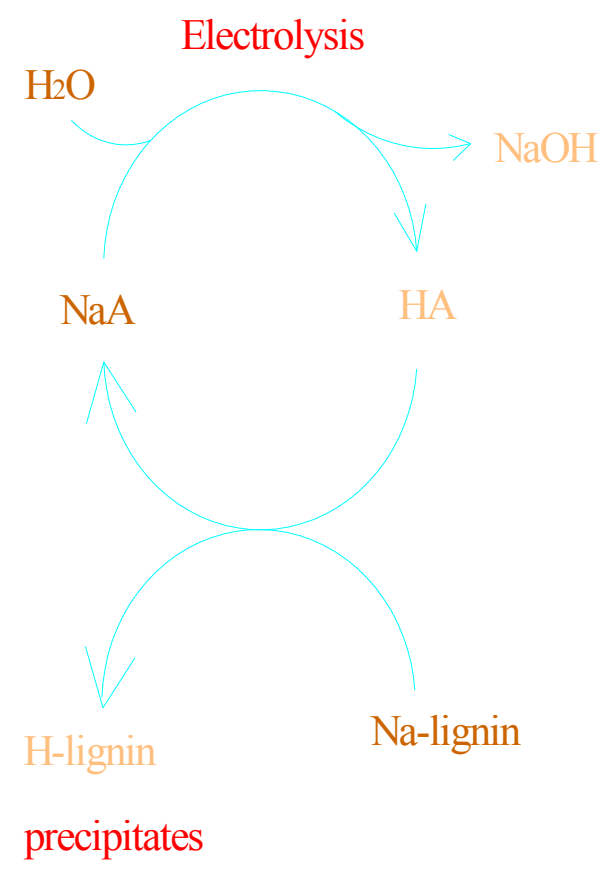

Figure 6. Mechanisms of lignin precipitating in the process of black liquor electrolysis.

The following reactions occur in the cathode chamber:

$$
\begin{array}{cl}
4 \mathrm{H}_{2} \mathrm{O} \rightarrow 4 \mathrm{H}^{+}+4^{-} \mathrm{OH} & \text { (1) (Water ionization) } \\
4^{-} \mathrm{OH}-4 \mathrm{e}^{-} \rightarrow 2 \mathrm{H}_{2} \mathrm{O}+\mathrm{O}_{2} \uparrow & \text { (2) (Anode reaction) } \\
\mathrm{NaA} \rightarrow \mathrm{Na}^{+}+\mathrm{A}^{-} & \text {(3) (Ion-dissociation reaction) } \\
\mathrm{H}^{+}+\mathrm{A}^{-} \rightarrow \mathrm{HA} & \text { (4) (Ion-binding reaction) } \\
\mathrm{HA}+\mathrm{Na} \text {-lignin } \rightarrow \mathrm{H} \text {-lignin } \downarrow+\mathrm{NaA} & \text { (5) (Ion-binding reaction) }
\end{array}
$$

The following reactions occur in the cathode chamber:

$$
\begin{array}{cl}
4 \mathrm{H}_{2} \mathrm{O} \rightarrow 4 \mathrm{H}^{+}+4^{-} \mathrm{OH} & \text { (1) (Water ionization) } \\
4 \mathrm{H}^{+}+4 \mathrm{e}^{-} \rightarrow 2 \mathrm{H}_{2} \uparrow & \text { (6) (Cathode reaction) } \\
4 \mathrm{Na}^{+}+4^{-} \mathrm{OH} \rightarrow 4 \mathrm{NaOH} & \text { (7) (Ion-binding reaction) }
\end{array}
$$

The net reaction for the electrolytic reactor is as follows:

$$
\text { Na-lignin }+\mathrm{NaA}+4 \mathrm{H}_{2} \mathrm{O} \rightarrow 2 \mathrm{NaOH}+\mathrm{H} \text {-lignin }+\mathrm{HA}+\mathrm{H}_{2} \uparrow+\mathrm{O}_{2} \uparrow
$$




\section{Discussion}

Treating black liquor by electrolysis consumes rather large amounts of electric energy, and thereby increases the electric energy consumption cost of a pulp mill. However, compared to combustion [6] and gasification [24], treating black liquor via electrolysis has the following advantages: (1) no need to concentrate the thin black liquor, which reduces the enormous amount of energy that is consumed during water evaporation; (2) no lime is consumed in the $\mathrm{NaOH}$ regeneration process, thereby, eliminating the energy intensive lime cycle, together with the necessary solid residue disposal system; (3) reduced emissions of $\mathrm{CO}_{2}$ gas and other poisonous gases [7]; (4) large-scale generation of lignin, which has potential to be converted into bioenergy and bio-materials $[13,25,26]$; (5) in addition to lignin, other organic components in the solution are recovered via polymerization, thereby reducing the amount of organic pollutants discharged.

Based on the numbers in Figure 2, the electric consumption for treating $1 \mathrm{~m}^{3}$ of black liquor is $96 \mathrm{kWh}$ that costs about $\$ 9.6 \mathrm{USD}$. The generated $\mathrm{NaOH}$ is about $30.7 \mathrm{~kg}$ that is worth about $\$ 10.7$ USD. Besides the $\mathrm{NaOH}, 52.1 \mathrm{~kg}$ of biomass solid and $0.82 \mathrm{~kg}$ of hydrogen are obtained at the same time; those two products are worth about $\$ 11.2$ USD. Therefore, although only $80.4 \%$ of $\mathrm{NaOH}$ was recovered, treating black liquor by electrolysis might be economically feasible. The detail economic calculations were shown in the Section 6 of the supplementary materials.

The black liquor electrolysis process has lots of potential: (1) the conventional black liquor recovery process in pulp mills discharges large amounts of solid, liquid and gaseous wastes that have a significant environmental impact on the surrounding areas [27], therefore, it is desirable to develop an alternative technology for processing black liquor; (2) the overall energy efficiency of the black liquor electrolysis process is much better than the conventional black liquor process via evaporation, combustion and the lime cycle; (3) treating black liquor by electrolysis generates biomass solids including lignin and other organic precipitates that can be converted to biofuels to substitute fossil fuels to reduce the $\mathrm{CO}_{2}$ emissions, and thereby benefit the environment [28]; (4) treating black liquor by electrolysis might be fitting to treat the black liquor generated from wheat straw, and the black liquor in a small-scale pulp mill, which get not allow good economic efficiency by installation of general recovery boilers.

\section{Conclusions}

A new black liquor treating system based on the electrolysis concept was studied. The main products were lignin sodium hydroxide, and hydrogen gas. Under the conditions studied, $1000 \mathrm{~mL}$ of black liquor ( $122 \mathrm{~g} / \mathrm{L}$ solid content) led to the generation of $30.7 \mathrm{~g}$ of sodium hydroxide, $52.1 \mathrm{~g}$ of biomass solids (containing $39.8 \mathrm{~g}$ of lignin and $12.3 \mathrm{~g}$ of polymers) and $0.82 \mathrm{~g}$ of hydrogen gas, while consuming a total of $345.6 \mathrm{~kJ}$ of electrical energy. Therefore, the recovery ratios of elemental sodium and biomass are $80.4 \%$ and $76 \%$, respectively. Treating black liquor via electrolysis is an environmentally friendly technology and represents an alternative technology that should be useful in addressing the environmental issues of the future.

Supplementary Materials: The following are available online at www.mdpi.com/1996-1073/9/1/13/s1.

Acknowledgments: The financial support for this project was provided by the Guangxi Natural Science Foundation (Grant \#: 2013jjFA20001).

Author Contributions: G.N. involved in the new ideal, spectrum analysis and manuscript preparation. S.W. involved in the device preparation. Z.Z. involved in preparation, determination and analysis of products. All authors reviewed the manuscript.

Conflicts of Interest: The authors declare no conflict of interest.

\section{References}

1. Hamaguchi, M.; Cardoso, M.; Vakkilainen, E. Alternative Technologies for Biofuels Production in Kraft Pulp Mills-Potential and Prospects. Energies 2012, 5, 2288-2309. 
2. Zeng, J.; Tong, Z.; Wang, L.; Zhu, J.Y.; Ingram, L. Isolation and structural characterization of sugarcane bagasse lignin after dilute phosphoric acid plus steam explosion pretreatment and its effect on cellulose hydrolysis. Bioresour. Technol. 2014, 154, 274-281. [PubMed]

3. Nong, G.; Huang, L.; Mo, H.; Wang, S. Investigate the variability of gas compositions and thermal efficiency of bagasse black liquor gasification. Energy 2013, 49, 178-181. [CrossRef]

4. Saw, W.L.; Nathan, G.J.; Ashman, P.J.; Hupa, M. Influence of droplet size on the release of atomic sodium from a burning black liquor droplet in a flat flame. Fuel 2010, 89, 1840-1848. [CrossRef]

5. Yang, C.Y.; Niu, Y.; Su, H.J.; Wang, Z.; Tao, F.; Wang, X.; Tang, H.; Ma, C.; Xu, P. A novel microbial habitat of alkaline black liquor with very high pollution load: Microbial diversity and the key members in application potentials. Bioresour. Technol. 2010, 101, 1737-1744. [CrossRef] [PubMed]

6. Maček, A. Research on combustion of black-liquor drops. Prog. Energy Combust. Sci. 1999, 25, $275-304$. [CrossRef]

7. Carlsson, P.; Wiinikka, H.; Marklund, M.; Grönberg, C.; Pettersson, E.; Lidman, M.; Gebart, R. Experimental investigation of an industrial scale black liquor gasifier. 1 . The effect of reactor operation parameters on product gas composition. Fuel 2010, 89, 4025-4034. [CrossRef]

8. Maciel, A.V.; Job, A.E.; Mussel, W.N.; Pasa, V.M.D. Pyrolysis and auto-gasification of black liquor in presence of $\mathrm{ZnO}$ : An integrated process for $\mathrm{Zn} / \mathrm{ZnO}$ nanostructure production and bioenergy generation. Biomass Bioenergy 2012, 46, 538-545. [CrossRef]

9. Naqvi, M.; Yan, J.; Dahlquist, E. Bio-refinery system in a pulp mill for methanol production with comparison of pressurized black liquor gasification and dry gasification using direct causticization. Appl. Energy 2012, 90, 24-31. [CrossRef]

10. García-Trenco, A.; Martínez, A. The influence of zeolite surface-aluminum species on the deactivation of CuZnAl/zeolite hybrid catalysts for the direct DME synthesis. Catal. Today 2014, 227, 144-153. [CrossRef]

11. Eriksson, H.; Harvey, S. Black liquor gasification-Consequences for both industry and society. Energy 2004, 29, 581-612. [CrossRef]

12. Zhang, X.; Wang, T.; Ma, L.; Zhang, Q.; Huang, X.; Yu, Y. Production of cyclohexane from lignin degradation compounds over $\mathrm{Ni} / \mathrm{ZrO}_{2}-\mathrm{SiO}_{2}$ catalysts. Appl. Energy 2013, 112, 533-538. [CrossRef]

13. Yoshikawa, T.; Shinohara, S.; Yagi, T.; Ryumon, N.; Nakasaka, Y.; Tagoa, T.; Masudaa, T. Production of phenols from lignin-derived slurry liquid using iron oxide catalyst. Appl. Catal. B 2014, 146, $289-297$. [CrossRef]

14. Welker, C.M.; Balasubramanian, V.K.; Petti, C.; Rai, K.M.; DeBolt, S.; Mendu, V. Engineering plant biomass lignin content and composition for biofuels and bioproducts. Energies 2015, 8, 7654-7676. [CrossRef]

15. Guo, F.; Xiu, Z.; Liang, Z. Synthesis of biodiesel from acidified soybean soapstock using a lignin-derived carbonaceous catalyst. Appl. Energy 2012, 98, 47-52. [CrossRef]

16. Minu, K.; Kurian Jiby, K.; Kishore, V.V.N. Isolation and purification of lignin and silica from the black liquor generated during the production of bioethanol from rice straw. Biomass Bioenergy 2012, 39, 210-217. [CrossRef]

17. Nong, G.; Chen, S.; Xu, Y.; Huang, L.; Zou, Q.; Li, S.; Mo, H.; Zhu, P.; Cen, W.; Wang, S. Artificial photosynthesis of oxalate and oxalate-based polymer by a photovoltaic reactor. Sci. Rep. 2014, 4. [CrossRef] [PubMed]

18. Han, B.; Steen, S.M., III; Mo, J.; Zhang, F. Electrochemical performance modeling of a proton exchange membrane electrolyzer cell for hydrogen energy. Int. J. Hydrogen Energy 2015, 40, 7006-7016. [CrossRef]

19. Ghatak, H.R. Electrolysis of black liquor for hydrogen production: Some initial findings. Int. J. Hydrogen Energy 2006, 31, 934-938.

20. Chen, Y.X.; Lavacchi, A.; Miller, H.A.; Bevilacqua, M.; Filippi, J.; Innocenti, M.; Marchionni, A.; Oberhauser, W.; Wang, L.; Vizza, F. Nanotechnology makes biomass electrolysis more energy efficient than water electrolysis. Nat. Commun. 2014, 5. [CrossRef] [PubMed]

21. Hong, J.G.; Zhang, B.; Glabman, S.; Uzal, N.; Dou, X.; Zhang, H.; Wei, X.; Chen, Y. Potential ion exchange membranes and system performance in reverse electrodialysis for power generation: A review. J. Membr. Sci. 2015, 486, 71-88. [CrossRef]

22. Chanda, D.; Hnát, J.; Paidar, M.; Schauer, J.; Bouzek, K. Synthesis and characterization of $\mathrm{NiFe}_{2} \mathrm{O}_{4}$ electrocatalyst for the hydrogen evolution reaction in alkaline water electrolysis using different polymer binders. J. Power Sources 2015, 285, 217-226. [CrossRef] 
23. Nie, X.; Luo, W.; Janik, M.J.; Asthagiri, A. Reaction mechanisms of $\mathrm{CO}_{2}$ electrochemical reduction on $\mathrm{Cu}(\mathrm{III})$ determined with density functional theory. J. Catal. 2014, 312, 108-122. [CrossRef]

24. Sricharoenchaikul, V.; Frederick, W.J., Jr.; Agrawal, P. Carbon distribution in char residue from gasification of Kraft black liquor. Biomass Bioenergy 2003, 25, 209-220. [CrossRef]

25. Lin, X.; Sui, S.; Tan, S.; Pittman, C.U., Jr.; Sun, J.; Zhang, Z. Fast pyrolysis of four lignins from different isolation processes using Py-GC/MS. Energies 2015, 8, 5107-5121. [CrossRef]

26. Wen, J.; Sun, S.; Yuan, T.; Xu, F.; Sun, R. Understanding the chemical and structural transformations of lignin macromolecule during torrefaction. Appl. Energy 2014, 121, 1-9. [CrossRef]

27. Bordado, J.C.M.; Gomes, J.F.P. Atmospheric emissions of Kraft pulp mills. Chem. Eng. Process. 2002, 41, 667-671. [CrossRef]

28. Budzianowski, W.M. Negative carbon intensity of renewable energy technologies involving biomass or carbon dioxide as inputs. Renew. Sustain. Energy Rev. 2012, 16, 6507-6521. [CrossRef]

(C) 2015 by the authors; licensee MDPI, Basel, Switzerland. This article is an open access article distributed under the terms and conditions of the Creative Commons by Attribution (CC-BY) license (http:/ / creativecommons.org/licenses/by/4.0/). 